\title{
Belonging: Concept, Meaning, and Commitment
}

\author{
Marcelo Zaffalon Peter \\ Universidade Federal de Santa \\ Catarina, Florianópolis, Brazil
}

\author{
Patricia Fares Jabbar Peter \\ Universidade Católica de Pelotas, \\ Pelotas, Brazil
}

\author{
Araci Hack Catapan \\ Universidade Federal de Santa \\ Catarina, Florianópolis, Brazil
}

The feeling of belonging distinguishes by the need to establish links that become significant and necessary for an individual's overall development. It emerges from the individual's experience and interaction with the world. Sense of belonging should also be contextualized in school life since it favors the teaching/learning process and students' motivation and participation. This paper tries to identify different forms of sense of belonging in the academic environment and their determinants. The methodology was a systematic review on electronic databases Latin American and Caribbean Health Sciences Literature (LILACS), SciELO, PubMed, Portal CAPES, and Google Scholar, including the studies published between January 2009 and October 2014. It is a theoretical study based on research and publications already accomplished in order to support a proposal for graduates' monitoring and evaluation. It is possible to highlight some contributions that feed a belonging relationship between students and teaching institutions. Therefore, it is clear the need to establish an ongoing dialogue between graduates and universities. Indicatives observed in this paper show that lived relations from students' admission time, in the academic environment, may develop a belonging sense and promote mutual, healthy, and lasting commitment. Thus, it is going to revert a constant update in its conceptual bases and curriculum organization for the institution, in view of constant changes in the working world. Also, it is going to allow continuous training and greater approach and commitment to the graduates. The study aims to develop a monitoring system proposal for graduates.

Keywords: belonging, membership, graduates

\section{Introduction}

The feeling of belonging distinguishes by the need to establish close and safe ties that generate a sense of security, care, and affection. It is an interpersonal relationship in which the emotional bond with the other becomes significant and necessary for an individual's overall development (Baumeister \& Leary, 1995; Skinner, Furrer, Marchand, \& Kindermamm, 2008). According to these authors, bond perception is essential to the belonging theory, and it makes people establish a minimum amount of meaningful relationships.

Maslow (1970) attributed significant value to the sense of belonging and social acceptance throughout life. The primary interest of belonging need is a psychological sense of being in a state of communion with others or a safe unit (Ryan \& Deci, 2004). Human beings need to live collectively or belong to a group that allows rooting and generates identity and social reference (Sousa, 2010). Sense of belonging is the biggest reason to form groups, communities, and societies. All people feel the need to belong— to be part of something through identification.

Marcelo Zaffalon Peter, post-doctoral fellow, Department of Education, Universidade Federal de Santa Catarina. Patricia Fares Jabbar Peter, Ph.D. candidate, Department of Health and Behavior, Universidade Católica de Pelotas. Araci Hack Catapan, Ph.D., professor, Department of Education, Universidade Federal de Santa Catarina. 
However, sense of belonging has a transitory characteristic since it follows individuals' social, cultural, and emotional state in that place, with that group, and at that time. According to Suertegaray, Basso, and Verdum (2000), sense of belonging appears from the interaction between global and local places and individuals' experiences with the world (involving natural and social dimensions that come true by interpretation, imagination, and projection while being material aspects). According to Gomes (2002), belonging mediation conveys the mediate to establish links that will anchor and provide a life story construction. He emphasized that:

(...) A human being needs to feel at home in order to maintain his/her mental health, in other words, he/she needs to belong to something, to recognize and be recognized, to identify and be identified by his/her peers, to have certain relationship, and to be part of a greater whole that welcomes and protects him/her. Belonging to something, beyond decentralizing from an egocentric omnipotence, nurtures a sense of pleasure and communion, since human beings cannot respond alone to their existential issues. (Gomes, 2002, p. 36)

According to Berger and Luckmann (2004), belonging regards to family ties, to be a member of a given society among other relationships that will extend with the establishment of bonds, references, and values.

Erickson (1987) also defined it on the basis of formal and informal organizations in which the individual participates in order to belong to an indentitarian group of mutual recognition among its members. Belonging includes communitarian relations, references constructs, guidelines values, behavior, and distribution of powers that are inherent to the community belonging. Individual participation, common language, and collective representations pass from one generation to another (Moscovici, 2009).

Yuval-Davis (2006) conceptualized belonging by describing three levels of understanding. The first level explores the notion of belonging by examining social positions, identification processes, emotional bonds, and ethical and political values. On the second level, it is possible to focus on belonging policies and how they integrate into various plans and projects of individuals that live in society, for example, citizenship right and participatory actions. This level shows the status right in a belonging group. The third level presents belonging mechanics structure in political, cultural, social, and religious projects comprising certain characteristics of an individual.

Bagnall (2009) added that the measure to reveal a subject's belonging depth appears in the forms of social organization and association with the communities experienced by the individuals. Therefore, when a person belongs to a particular group, he/she becomes, at the same time, a recognized member of the community as a whole and still assumes his/her belonging to that culture.

School life should also contextualize the belonging sense. The school is a vital place for construction and reflection of belonging meaning, having an identity and sharing a model that gathers ethics, morality, affection, and knowledge (Souza, 2014). One of the ways in which the process of becoming a student happens is through the construction of his/her identification modes originated by experiences gained throughout the school life.

Students can legitimize their identity in different living contexts through belonging. Sense of belonging becomes of fundamental importance to students regarding the teaching/learning process, because if they realize the insertion into the system, they will feel more empowered, productive, and motivated. Students recognize the importance of school activities involvement in a positive and warm environment that generates a sense of belonging and acceptance.

In the school environment, motivation has been investigated as an important triggering factor for learning as a motivated student is the one involved, attentive, and faces new tasks and new search strategies to solve problems. On the other hand, school failure is almost always associated with interpersonal and behavioral 
relationships. Thus, it is possible to understand that the sum of these positive, negative, and traumatic experiences makes the individual turn viable his/her belonging forms in and out of school.

Starting from these considerations, one might think that the experiences lived by the student serve as references when he/she enters into the working life. Development of bonds, experiences, roots needs, safety, and academic life are part of the relationship between graduates and educational institutions. Belonging sense acts as a motivating factor for an individual's professional success and continuous training process. The institution may consider that sense as a feedback process. Identifying and understanding the sense of belonging generated in the graduates can be a valuable indicator for the educational institution in order to enhance its curricular organization. It may happen not only through a better professional training, but also with a better contribution to the general training of individuals and society.

Based on that assumption, the present research sought to identify, through a systematic review, different ways of sense of belonging in the academic environment and its determinants. It is not an empirical study, but a theoretical one from research and publications already held in order to support a proposal for graduates' monitoring and evaluation.

\section{Sense of Belonging}

In order to understand the concept treatment over a period of five years, there was a systematic, descriptive, and exploratory review in the following electronic databases: Latin American and Caribbean Health Sciences Literature (LILACS), SciELO, PubMed, Portal CAPES, and Google Scholar. Descriptors used were "feeling of belonging", "school", and their combinations. Research period included studies (both in English and Portuguese) published between January 2009 and October 2014 (see Table 1).

Table 1

Systematic Review

\begin{tabular}{llrr}
\hline Databases & Descriptors & Total of articles & $2009-2014$ \\
\hline \multirow{3}{*}{ SciELO } & Belonging & 195 & 107 \\
& Belonging + school & 23 & 17 \\
& Belonging + membership & 311 & 164 \\
\hline \multirow{3}{*}{ LILACS } & Belonging & 281 & 121 \\
& Belonging + school & 17 & 7 \\
\hline \multirow{2}{*}{ PubMed } & Belonging + membership & 281 & 121 \\
& Feeling of belonging & 472 & 214 \\
\multirow{3}{*}{ Google Scholar } & Feeling of belonging + school & 105 & 53 \\
& Belonging & 58,800 & 16,900 \\
& Belonging + school & 54,500 & 15,000 \\
\multirow{2}{*}{ Portal CAPES } & Belonging + membership & 10,500 & 7,760 \\
& Belonging & 928 & 696 \\
Total & Belonging + school & 314 & 259 \\
\hline
\end{tabular}

Note. Source: Produced by the authors.

\section{Results}

It was possible to find that several studies highlight the importance of belonging in different contexts and 
populations after carrying out the systematic review. Nevertheless, a few specific articles are related to this study. In total, 41,462 articles were found in the period between the years 2009 and 2014; then, only 15 contemplated criteria inclusion and they were special studies related to belonging and academic context (see Table 1).

When developing belonging sense concept, Mahar, Cobigo, and Stuart (2013) defined it as subjective, derived from a reciprocal relationship developed from shared experiences, beliefs, or personal characteristics. Therefore, the satisfaction of competence, autonomy, and belonging favors emotional engagement and motivation, as stated by Ferreira (2010).

Sense of belonging to the school, according to Shochet, Smith, Furlong, and Homel (2011), is a predictor of emotional problems in adolescents. Ceia (2011) concluded in his case study the same because he found that a negative school climate can bring insecurity according to the students' perception. Walton and Cohen (2011) verified that students who felt more belonging to the academic environment felt happier, presented more social interaction, and improved their well-being sense when they investigated freshmen transition to the university.

In assessing the partnership between school and community, Bezerra, Sena, Dantas, Cavalcante, and Nakayama (2010) found that the members have greater involvement in school activities when they feel that they belong to it. Souza (2014) verified the relationship between belonging sense and school property depredation. Then, if relations among actors are more complex in the educational process, their involvement, commitment, and opportunities will be greater to develop a belonging sense. Similarly, Oliveira and Ribeiro (2014) performed a survey along with teachers, students, and employees. They observed that some everyday elements generate a belonging sense, such as the institution history knowledge in general and images that remain recorded in the memory of those who lived or are living part of their lives in that place.

Research contributions by Castro (2011) about identity, as well as belonging concepts, can be a reference for pedagogical actions. They favor students' autonomy and criticality while they develop a constant dialectical motion in the search for flexibility, interaction, and belonging in school spaces.

Belonging relates to ties that will extend with the establishment of bonds, references, and values. Rodrigues and Ferreira (2012) pointed out in their qualitative approach towards school management and emphasized the professional belonging sense in the teachers' work, the need for recognition in a collective approach. Thereby, a subject feels belonging to the context through his/her job and recognition, and in that process, he/she develops collectivity sense. "It is at workplace and their jobs that teachers act in school management, and then, they develop their professional belonging. Education challenges and prospects depend on collective efforts” (Rodrigues \& Ferreira, 2012, p. 13).

A research presented by Farina and Trarbach (2009) points to the need for inclusive practices aimed at individual and collective development. Such considerations were also highlighted by Nascimento (2010), Amaral and Baibic-Faria (2012), and Cruz (2014). After investigating ethnic identity processes, they realized that there could be, in these groups, a double belonging sense or discrimination expressions in the interactions; therefore, it appears the identity affirmation importance as a subject and socialization access.

\section{Belonging and Egressed Students: Mutual Contribution}

It is possible to develop contributions for a constant approximation between universities and graduates by assessing the belonging sense importance in an individual's global development and drawing transversality 
with educational institutions at different levels of training.

Educational institutions characterize primarily by being recognized spaces of values socialization, with personal and professional ties. They promote construction and consolidation of innovative knowledge before the challenges needed for new and constant knowledge configuration.

According to Ramos et al. (2010), regardless the use of specific plans and methods, evaluation is an essential element of any social action to the extent that subsidizes criticism and position taking with information about the operation of a program, service, or action. It happens in terms of results and impacts, such as operability and processes involved that may indicate new demands, goals, or strategies for the desired quality.

When a program reaches certain level of maturity, it is essential to examine, evaluate, and reflect on the success of the professionals' training and performance. It can only be done through mapping and analysis of graduates' trajectory (Underwood, Nault, \& Ferguson, 1994; Ingram, Haynes, Davidson-Shivers, \& Irvin, 2005).

Furthermore, graduates may become strategic informants in the labor market, contributing to improvements in the training offered. Also, it is worth mentioning that graduates in key positions, either in the academic environment or other sectors of activity are fundamental contacts for new program's participants. It will be possible to obtain these advantages if the course or post-graduation program has systematic and continuous contact with a significant part of its graduates (Underwood et al., 1994).

For Moreira and Velho (2012), it is evident the need for more dialogue between training institutions sectors to discuss possible alternatives in order to improve integration of professional and scientific training. Moreover, it is necessary to follow up graduates, because it is a way to establish harmony between the labor market and educational institutions. It is worth encouraging continuing education, as well as interdisciplinary seminars performance, technical workshops on writing and culture, tutorials, and instructive experiences.

Thus, it is necessary to develop internal mechanisms of approach among people involved in the teaching/learning process from the start in order to create a belonging sense. Then, the institution is going to have an efficient model of graduates' monitoring and evaluation. Thereby, there must be a constant concern for training critical, conscientious, and ethical professionals who are technically allied to the professionalization. They have to promote global training for individuals in a natural and comprehensive way, with responsibility for the collective well-being, ensuring personal, professional, and institutional growth.

\section{Conclusion}

It is possible to realize that sense of belonging appears in individual and collective aspects, and increases even more in the search for identity and reference in all contexts.

A subject, in his/her singularity, develops feeling of appreciation, recognition, and commitment in social interactions. He/she also builds his/her identity and personal and social performance. That feeling, considered as belonging to the present research, may feed a personal self-training, as well as a feedback towards the institutions in which the subject studied or studies.

An individual, throughout his/her school trajectory, develops a sense of belonging when sharing expectations, experiences, feelings, commitments, and achievements. He/she builds possibilities for his/her personal, professional, political, religious, and intellectual career by continuous and circular motion.

It is possible to realize that institutions developing a continuous relationship with graduates are more likely to evolve and keep updated and gathered with society. The challenge is to organize and develop a 
graduates' monitoring model to feed bonds of experiences' interaction in direct coexistence. The systematic review conducted for the study indicates some ways. However, it is worth considering that each institution has its nature, context, and purposes, and each person has his/her expectations and needs. Combination of these two interest sources in a continuous, dynamic, and relevant programming can be one of the elements of success for any organization.

The challenge requires a particular methodology, through dynamic and interactive tools, that provides conditions to maintain a link between the educational institution and a group of graduates. It becomes increasingly necessary to build useful tools in order to promote that approach. It is possible to promote mutual, healthy, and lasting commitment through belonging relations experienced from students' admission in the academic environment. Then, it will ensure for the institution a constant update in its curricular base and according to the transformation dynamics in the working world. Developing a graduate monitoring system may feed a continuing training program and strengthen ties between the university and society.

\section{References}

Amaral, W. R., \& Baibic-Faria, T. M. (2012). A presença dos estudantes indígenas nas universidades estaduais do Paraná: Trajetórias e pertencimentos (The presence of native students in Parana universities: Trajectory and belonging). Revista Brasileira de Estudos Pedagógicos (Brasília), 93(235), 818-835.

Bagnall, N. F. (2009). Re-imaginando a escola: Educação e pertencimento (Thinking about the school: Schooling and belonging). Lecture realized in The 3rd Meeeting About Education, Citizenchip, and Exclusion: Gender and Poverty—School Images, University of Rio de Janeiro, Rio de Janeiro.

Baumeister, R. F., \& Leary, M. R. (1995). The need to belong: Desire for inter personal attachments as a fundamental human motivation. Psychological Bulletin, 117(3), 497-529.

Berger, P. L., \& Luckmann, T. (2004). Modernidade, pluralismo e crise de sentidos: A orientação do homem modern (Modernity, pluralism and sight crises: Modern man orientation). Petrópolis: Vozes.

Bezerra, Z. F., Sena, F. A., Dantas, O. M. S., Cavalcante, A. D., \& Nakayama, L. (2010). Comunidade e escola: Reflexões sobre uma integração necessária (Comunity and school: Reflections about necessary integration). Educar, 37, 279-291.

Castro, P. A. (2011). Tornar-se aluno: Identidade e pertencimento: Um estudo etnográfico (Being a student: Identity and belonging: Etnographic study) (Ed.D. dissertation, Faculty of Education, State University of Rio de Janeiro).

Ceia, A. M. R. (2011). Um olhar de dentro: O clima de escola na perspectiva dos alunos (Looking inside: School environment by students perspectives) (Master's thesis, Department of Education and Distance Learning, Open University, Portugal).

Cruz, T. M. (2014). Espaço escolar e discriminação: Significados de gênero e raça entre crianças (School space and discrimination: Gender and race meaning between the kids). Educação em Revista, 30(1), 157-188.

Erickson, F. (1987). Conceptions of school culture: An overview. Educational Administration Quarterly, 23(4), 11-24.

Farina, B. C., \& Trarbach, D. M. (2009). Inclusão e a formação de lugares: Do pertencimento à estigmatização (Inclusion and formation of places: From belonging to estigmatization). Proceedings of The National Meeting in Teaching Practice in Geography. Porto Alegre: ENPEG.

Ferreira, E. E. B. (2010). A percepção de competência, autonomia e pertencimento como indicadores da qualidade motivacional do aluno (Perception of competence, autonomy and belonging as indicators of student motivational quality) (Ed.D. dissertation, Faculty of Philosophy and Sciences, Universidade Estadual Paulista Julio de Mesquita Filho, Marilia).

Gomes, K. C. (2002). Relações de família: A complexidade dos grupos multi familiares do Programa Rede de Apoio e Proteção à Família (Family relationship: Complexity of familiar groups from Family Protection and Help Program) (Master’s thesis, UFRGS, Porto Alegre).

Ingram, K., Haynes, L., Davidson-Shivers, G., \& Irvin, R. (2005). Building an alumni support community: Tracking alumni for program evaluation and added value. Retrieved from http://www.freepatent online.com/article/ College-Student Journal133 606091.html

Mahar, A. L., Cobigo, V., \& Stuart, H. (2013). Conceptualizing belonging. Disabil Rehabil, 35(12), 1026-1032.

Maslow, A. (1970). Motivation and personality. New York, N.Y.: Harper \& Row Publishers. 
Moreira, M. L., \& Velho, L. (2012). Trajetória de egressos da pós-graduação do Instituto Nacional de Pesquisas Espaciais: Uma ferramenta para avaliação (Graduates trajectory from spaces research: Tool for avaliation). Avaliação, 17(1), 257-288.

Moscovici, S. (2009). Representações sociais: Investigações em psicologia social (Social representation: Investigating in social psychology) (6th ed.). (A. G. Pedrinho, Trans.). Petrópolis: Vozes.

Nascimento, D. (2010). Relações interétnicas em uma escola pública no sul do Brasil: 1951-1964 (Interethnics relations in public schools in south of Brazil: 1951-1964). Educar, 37, 241-257.

Oliveira, E. T., \& Ribeiro, A. I. M. (2014). Leitura semiótica e reconstrução histórica: Análise de imagens da manifestação pela manutenção da UNESP (Semioptical reading and history reconstruction: Images analysis of manifestation for UNESP maintenance). Discursos Fotográficos, 10(16), 135-162.

Ramos, F. R. S., Backeses, V. M. S., Backeses, D. S., Schneider, D. G., Pinheiro, G., Zeferinol, M. T., \& Rochal, P. K. (2010). Formação de mestres em enfermagem na Universidade Federal de Santa Catarina: Contribuições sob a ótica de egressos (Master nurse schooling from Santa Catarina Federal University: Graduates contributions). Revista Brasileira de Enfermagem (Brasília), 63(3), 359-365.

Rodrigues, I. D. W. M., \& Ferreira, L. S. (2012). Relações entre gestão escolar e pertença profissional no discurso de professoras iniciantes (Relation between school management and professional belonging in begginer teachers). Rio de Janeiro: Workshop School Research from South Region, ANPED.

Ryan, R. M., \& Deci, E. L. (2004). Overview of self-determination theory: An organismic dialectical perspective. In E. L. Deci, \& R. M. Ryan (Eds.), Handbook of self determination research. Rochester, N.Y.: University of Rochester Press.

Shochet, I. M., Smith, C. L., Furlong, M. J., \& Homel, R. A. (2011). Prospective study investigating the impact of school belonging factors on negative affect in adolescents. Journal of Clinical Child, Adolescent Psychology, 40(4), 586-595.

Skinner, E., Furrer, C., Marchand, G., \& Kindermamm, T. (2008). Engagement and disaffection in the classroom: Part of larger motivational dynamic? Journal of Educational Psychology, 100(4), 765-781.

Sousa, M. W. (2010). O pertencimento ao comum mediático: A identidade em tempos de transição (Belonging to common: Identity in transition times). Significação, 34, 31-52.

Souza, M. P. (2014). O sentimento de pertencimento à escola e a depredação do patrimônio escolar (Feeling of school belonging and school patrimony descruction). Tribuna do Planalto, 29(1), 448.

Suertegaray, D. M. A., Basso, L. A., \& Verdum, R. (2000). Ambiente e lugar no urbano: A grande Porto Alegre (Environment and urban space: Porto Alegre). Porto Alegre: Editora da Universidade.

Underwood, D., Nault, E., \& Ferguson, L. (1994). Sometimes more is better: Development and implementation of a graduate alumni survey to increase response rates and evaluate strategic planning. New Orleans, L.A.: Association of Institutional Research.

Walton, G. M., \& Cohen, G. L. (2011). A brief social-belonging intervention improves academic and health outcomes of minority students. Science, 331(6023), 1447-1451.

Yuval-Davis, N. (2006). Belonging and the politics of belonging. Patterns of Prejudice, 40(3), 197-214. 